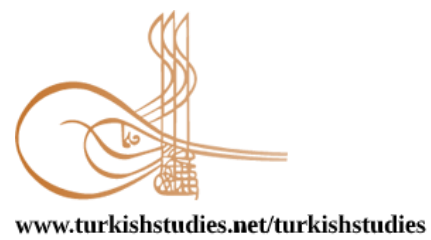

Turkish Studies

www.turkishstudies.net/turkishstudies

eISSN: $1308-2140$

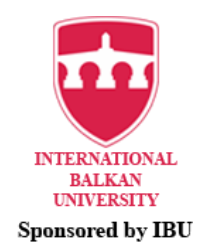

Letter to Editor / Editöre Mektup

\title{
COVID-19 Pandemisinin Sonuçları Beslenme Alışkanlığımızı Değiştirebilir mi? Bir Tercihten Bir Gereksinime Dönüş
}

Can the Results of the COVID-19 Pandemic Change Our Nutrition? Return from A Preference to a Requirement

\author{
Çağatay Üstün* - Seçil Özçiftçi **
}

Sayın Editör;

Aralık 2019'da Çin'in Hubei eyaleti Wuhan kentindeki canlı hayvan pazarından yayıldığı söylenen bir hastalık kısa sürede pandemi şekline dönüşerek, dünya geneline yayıldı. Halen COVID-19 olarak tanımlanan bu hastalıktan dünya genelinde enfekte olanların sayıs1 25.775.330 ölenlerin say1s1 857.431'dir (WORLDOMETERS, 2020).

Hastalık hakkında paylaşılan bilgilendirmelerde etken virüsün zoonotik karakterde olduğu, yarasalardan insana geçtiği belirtilmiştir (Mackenzie et al., 2020; Chan et al., 2015). Zoonotik karakterde gıdalarla beslenme alışkanlığının özellikle iklim değişikliğinde insan ve bazı hayvan popülasyonlarını etkilediği düşünülmektedir (McIntyre et al., 2017). Bu etkileşim tarım ve gıda faaliyetlerinin artması, ticaretin küreselleşmesi ve biyolojik çeşitliliğin azalması gibi diğer küresel değişikliklerle birleştiğinde, zoonotik etken kaynaklı bulaşıcı hastalıkların, istenmeyen durumlara ve gelecekte yaşanacak muhtemel krizlere sebep olabileceği belirtilmektedir. Beslenme alışkanlığı ve gıda temini konusunda hayvansal kaynaklı gıdaların zoonotik ve antimikrobiyal dirençle ilgili hastalıklara sebep olacağının kaçınılmaz olduğu düşünüldüğünde bu konuya yönelik kapsamlı ve multidisipliner risk azaltma çalışmaları yapılması gerektiği gündeme gelebilir (Binot et al., 2019).

Belki de kısa bir zaman içinde günlük gıdalarımızın hayvansal ağırlıklı olmasının getirdiği sağlık sorunlarını ve çevresel kirlenmeyi minimalize etmek için vejetaryen bir beslenme alışkanlığına yönelmek bir tercih sebebi olacaktır.

\footnotetext{
* Prof. Dr. Ege Üniversitesi Tıp Fakültesi, Tıp Tarihi ve Etik Anabilim Dalı

Prof. Dr. Ege University Faculty of Medicine, History of Medicine, Ethics Department

ORCID 0000-0001-7834-6616

cagatay.ustun@hotmail.com

** Uzm. Hem. Ege Üniversitesi, Tıp Fakültesi Hastanesi

Researcher Nurse, Ege University Faculty of Medicine

ORCID 0000- 0002-7320-961X

ozciftcisecill@gmail.com
}

Cite as/ Atıf: Üstün, Ç. \& Özçiftçi, S. (2020). COVID-19 pandemisinin sonuçları beslenme alışkanlığımızı değiştirebilir mi? bir tercihten bir gereksinime dönüş. Turkish Studies, 15(4), 1443-1445. https://dx.doi.org/10.7827/TurkishStudies.45963

Received/Geliş: 26 August/Ağustos 2020

Accepted/Kabul: 30 August/Ağustos 2020

Checked by plagiarism software

Copyright (C) MDE, Turkey 
Bugün dünyada vejetaryenlik oranının en yüksek olduğu ülke Hindistan (\%38) olarak bilinmektedir. Diğer ülkelerde bu oranın daha düşük olduğu görülmektedir. Örneğin Avustralya (\%5), Brezilya (\%8), Birleşik Krallık (9), İtalya (\%10), İsrail (\%13) gibi.

Vejetaryanizm kısaca bitkilerden elde edilen yiyecekler ile beslenerek, et ürünlerinden uzak durmak şeklinde tanımlanabilir. Bu anlayış dini, etik motivasyon sağlama, hayvan refahı talebi, kültürel gerekçeler, sağllklı olma, ekonomik etkiler, çevreyi koruma gibi faktörlere dayanmaktadır (WORLDATLAS, 2020). Yapılması gereken öneri, endüstriyel üretim şekline dönüşmüş et ve süt ürünlerinin oluşturduğu çevresel olumsuzluklara karşı bireysel duyarlılık oluşturmaya yöneliktir.

$\mathrm{Bu}$ arada, WHO'nun yaptığı COVID-19 virüsünün hayvansal yağda hayatta kalması sebebiyle vejetaryenlerin korunduğuna ilişkin ileri sürülen iddianın doğruluğunun saptanmadığı belirtilmektedir. Ancak hastalığın başlangıcından beri zoonotik karakterdeki virüslerin insana bulaşma riski ve az pişmiş veya çiğ et tüketiminin bu tür hastalık zincirinin bir parçası olacağ fikirleri geçerliliğini sürdürmektedir (SNOPES, 2020). Hayvansal ürünlerin yetiştirilmesindeki süreçlerin maliyetli olması, temizlik şartlarının sağlanmasında ortaya çıkan zorluklar, hastalığın bir et marketinden çıkmış olması bu tür beslenme alışkanlığının sorgulanması gerektiğine işaret etmektedir.

COVID-19 pandemisinden çıkarılan bir başka ders, vahşi hayvan ticaretine ve bu tür ürünlerin tüketimine son verilmesi üzerinde odaklanmaktadır. Doğal yaşamı tehdit eden ve halk sağlığı sorunu oluşturan bu yıkıcı ve olumsuz durumun sağlığımızı bozacak unsurları ortadan kaldırmas1 beklenmektedir (THEREVELATOR, 2020). COVID-19 sürecinde hastalıktan korunması için sağlıklı ve dengeli bir beslenmenin ve vitamin, mineral takviyesinin önemine değinilmesi yol göstericidir (EUFIC, 2020). Bu çıkış noktasından hareketle, vejetaryen beslenme içeriğinin doğru anlaşılır boyutlarıyla ikna edici araştırmaların beslenme ve viral hastalıklar, immün sistemin güçlenmesi, enfekte olma ve prognoz arasındaki bağlantı üzerinde yoğunlaşması konunun önemini ortaya çıkaracaktır. Halen bu başlıklar hakkında yapılmış yeterli ve destekleyici bir kanıt bulunmamaktadır. Ancak gelecekte vejetaryenliğe ait öneriler sayesinde hayvandan insana geçebilen hastalıkların azaltılması anlamında bir gelişme sağlanabilir kanısındayız. Menülerdeki yeşil beslenme alternatiflerinin çoğaltılması, tarımsal ürünlerin geliştirilmesi sayesinde hayvansal beslenme stratejilerinden bu yöne bir eğilim mümkün olabilir. Bu sayede, bir tercihten bir gereksinime doğru yaşanacak dönüş, beklenenin ötesinde bir başarıya zemin hazırlayabilir.

\section{Kaynakça}

Binot, A., Cilas, C. Risks Of New Pests And Diseases. (2019). Food Systems At Risk New Trends And Challenges. Rome, Montpellier, Brussels, FAO, CIRAD and European Commission, 47-50.

Chan, JF., Lau, SK., To, KK., Cheng, VC., Woo, PC., Yuen KY. (2015). Middle East respiratory syndrome coronavirus: another zoonotic betacoronavirus causing SARS-like disease. Clin Microbiol Rev, 28(2):465-522.

EUFIC. (2020). Food and coronavirus (COVID-19): what you need to know https://www.eufic.org/en/food-safety/article/food-and-coronavirus-covid-19-what-youneed-to-know

Mackenzie, JS., Smith DW. (2020). COVID-19: A novel zoonotic disease caused by a coronavirus from China: what we know and what we don't. Microbiology Australıa. MA20013. 
McIntyre, KM. Setzkorn, C., Hepworth, PJ., Morand, S., Morse, AP., Baylis, M. (2017). Systematic assessment of the climate sensitivity of important human and domestic animals pathogens in Europe. Scientific Reports, 7(1): 7134.

SNOPES. (2020). Are Vegetarians Safe from COVID-19? https://www.snopes.com/factcheck/vegetarians-safe-from-covid19/

THEREVELATOR. (2020). How COVID-19 Took Hold and Why We Must End the Wildlife Trade https://therevelator.org/coronavirus-wildlife-trade/

WORLDATLAS. (2020). Countries With The Highest Rates Of Vegetarianism https://www.worldatlas.com/articles/countries-with-the-highest-rates-ofvegetarianism.html

WORLDOMETERS. (2020). Covid-19 Coronavirus Pandemic. https://www.worldometers.info/coronavirus/ 